\title{
Perceptions of the Mahir Mahar Housing Complex Community about the Weekly Market During the COVID-19 Pandemic on Jalan Tangkalasa Palangka Raya
}

\author{
Windy Utami Putri ${ }^{1, *}$ Rinto Alexandro ${ }^{2}$
}

${ }^{1,2}$ Economic Education Study Program, Faculty of Teacher Training and Education, Indonesia.
${ }^{*}$ Corresponding author. Email: windyutamiputri@fkip.upr.ac.id

\begin{abstract}
This study aims to determine the community's perception of the Mahir Mahar housing complex about the Weekly Market during the COVID-19 pandemic on Jalan Tangkalasa Palangka Raya. In this study using qualitative research which reveals the phenomena in society using descriptive methods. The result of this research is the existence of a weekly market in the Mahir Mahar housing complex km.8 Palangka Raya is approved by residents, the community feels that the weekly market is useful in the Mahir Mahar housing complex. In addition, there is also interaction between the community and traders in the weekly market. The public has the perception that the weekly market environment is dirty and only partly and does not fully implement health protocols to prevent COVID-19. The weekly market has conducive security and the quality of goods sold is still fresh at affordable prices.
\end{abstract}

Keywords: COVID-19, Society, Weekly market

\section{INTRODUCTION}

The market in people's lives has an important role. In the market, people can meet needs and become an economic driver. The market is a place for buying and selling transactions between sellers and buyers. Gathering of sellers to sell their wares and gathering of buyers to fulfill their needs. This makes the market important for regional economic activity. In line with what was said in the journal [1] that "weekly market is a gathering of consumers or people for a certain period for the purpose of buying and selling, i.e., exchanging goods and services, and even ideas, tangible and intangible, are exchanged "

The market has many types, depending on whether they are differentiated according to their function or types. There are also markets that are differentiated according to time, namely daily markets, weekly markets, monthly markets and annual markets. Daily markets are held every day, weekly markets are held once a week, monthly markets are held once a month and annual markets are held only once a year. This is as expressed by [2], namely "Local weekly markets are a traditional style of retailing where on a particular day of a week petty traders display their commodities on a makeshift arrangement in places authorized by the state municipal authorities against payment of some fixed remuneration. Usually these markets are organized on pavements of the roads."

In the city of Palangka Raya, there are many traditional markets, including the Kahayan market, the Blauran market, the Lombok market, and the Rajawali market. Although there are many markets, some of these traditional markets are still far from the residences of Palangka Raya residents which are not in the city center. This has resulted in many people visiting the weekly market held in the surrounding area.

One of the weekly markets in the Palangka Raya City area is located on Jalan Mahir Mahar, Km.8 Rajawali. This weekly market is held every night of the week at the BTN Housing Complex which is a part of the Lais, Tangkalasa, and Mahir Mahar housing complexes. This weekly market is held on a field in front of the complex. This field is also the location of the street vendors selling every day.

People who live in the Mahir Mahar housing complex take advantage of the weekly market which is 
held every Saturday afternoon or to be precise on Sunday evenings. So that in the market there is social interaction. From this social interaction, there are many kinds of perceptions from the community, both regarding the benefits of the existing market, then environmental conditions, security, social interactions, and also about education and customs.

The whole world is facing the COVID-19 Virus, as well as in Indonesia. SARS-CoV-2 or COVID 2 is a virus from the beta type of coronavirus that can cause mild to severe respiratory problems. The COVID-19 virus has a higher transmission rate than SAR-CoV or MERS. The incubation period for the virus is $0-24$ days with the mean from first symptoms to death being 3-14 days. However, this period varies and will be faster when the patient gets older [10]

During the COVID-19 Pandemic this affected various community activities. One of them also affects community activities in the weekly market in Mahir Mahar housing. Preventing the transmission of the COVID-19 virus is something that absolutely must be done by the community but on the other hand, it must also meet needs and earn income by interacting in this weekly market. The existence of markets, social interactions, hygiene, security and market merchandise have changed since the pandemic. This change is not known in detail so that further investigation is needed.

Based on the description above, the authors are interested in studying and analysing people's perceptions of the weekly market in their housing complex during this pandemic. For this reason, the authors conducted a research entitled "Perceptions of the Community of Mahir Mahar Housing Environment about the Weekly Market during the COVID-19 Pandemic on Jalan Tangkalasa Palangka Raya"

The purpose of this research is to find out:

1) Community perceptions of Mahir Mahar Housing, Palangka Raya about the existence of the market during the COVID -19 pandemic

2) Community perceptions of Mahir Mahar Housing, Palangka Raya about the benefits of the market during the COVID -19 pandemic

3) Community perceptions of the Mahir Mahar Housing Environment, Palangka Raya about social interactions during the COVID-19 pandemic

4) Community perceptions of the Mahir Mahar Housing Environment, Palangka Raya about cleanliness during the COVID -19 pandemic

5) Community perceptions of Mahir Mahar Housing, Palangka Raya regarding security during the COVID-19 pandemic
6) Perceptions of the community in Mahir Mahar Housing, Palangka Raya about the quality of market trade during the COVID-19 pandemic

\section{LITERATURE REVIEW}

According to [3]"perception is an observation, the arrangement of forces in unity, knowing things, through the senses, responses (senses) and the power to understand". Observation and encouragement are part of perception. As stated by [4] "perception is a set of mental actions that regulate sensory impulses into a meaningful pattern".

It argues that humans are "zoon politicons", namely social beings who only like to live in groups or at least seek mutual friends rather than live alone [5] Humans are social creatures who need to always socialize. In addition, Stephen K. Sanderson [6] argues that "society is a complex system consisting of interconnected and interdependent parts and each part significantly influences the other parts" . So, community perception is a process where groups of people who live together in an area and provide an understanding or response to things or events that occur in their environment.

Many factors influence the perception that exists in society, namely those originating from within and from outside the individual. This is consistent with what [5] said that "Perception arises because of two factors, both internal and external. Internal factors depend on the process of understanding something including the value system, goals, beliefs and responses to the results achieved. These two factors give rise to perceptions because they are preceded by a process known as communication." Presidential Regulation of the Republic of Indonesia No. 112 of 2007 [7] states that: "Market as an area for buying and selling goods with more than one number of sellers, which is called a shopping centre, traditional market, shops, malls, plazas, trade centers or other names". The market has various kinds that can be divided into several things. It is also stated "the market as a regional company is classified according to several things, namely by type of activity, according to location and service capability, according to the time of activity, and according to ownership status."

Reference [8] writes about "The Role of Traditional Markets as a Basic Foundation for a Populist Economy". The research results show that traditional markets are one of the heart of the community's economy, the role of markets is very vital for the national economy. Apart from being the basic foundation of the economy, traditional markets can also be used to maximize agricultural products managed by farmers. Reference [9] wrote about "The existence of the Tais Weekly Market in the city of Bengkulu." The results of the study revealed that the Tais weekly market 
is a market carried by local residents and is held once a week with the location being land owned by local residents that are rented by traders

Markets according to time such as daily markets, weekly markets, monthly markets and annual markets already exist in the city of Palangka Raya. The weekly market, which is held once a week, has already started to be held in the city of Palangka Raya. Many of the weekly markets are located in strategic areas. This strategic location is located in a residential complex area that is far from traditional markets. The weekly market carries out the buying and selling process not from the morning or afternoon, but at night.

\section{METHOD}

The author of this study uses qualitative research. This research reveals the phenomenon in society by using descriptive methods.

Sources of data in this study are researchers, informants consisting of the head of the RT and the community in Mahir Mahar housing. The researchers' techniques in collecting the data were questionnaires and documentary studies. The data analysis technique used in this study was the Miles and Huberman Model. Activities carried out in this data analysis are Data Reduction, Data Display, Conclusion Drawing/ Verification.

\section{RESULTS AND DISCUSSION}

\subsection{Perceptions of the Mahir Mahar} Housing Complex Community about the existence of the weekly market during the COVID-19 pandemic on Jalan Tangkalasa, Palangka Raya.

The following table 1 contains a recapitulation of public perceptions of the existence of the weekly market. From the analysis of each question item regarding the existence of the market, it can be concluded that the existence of the weekly market in the Mahir Mahar housing complex is approved by the community. This can be seen in the recapitulation table that the answers "agree" as much as 6 question points and "strongly agree" 1 question point.

\subsection{Perceptions of the Mahir Mahar Housing Complex Community about the Benefits of the Weekly Market during the COVID-19 Pandemic on Jalan Tangkalasa, Palangka Raya.}

The results of the analysis of each question item regarding the benefits of the market (Table 2) can be concluded that the weekly market in the Mahir Mahar housing complex is beneficial for the surrounding community. This can be seen in the recapitulation table that of the 7 points the question answers "agree".

Table 1. Recapitulation of Public Perceptions Regarding the Existence of the Weekly Market in the Mahir Mahar Housing Complex Indicators of Market Existence

\begin{tabular}{|c|c|c|c|c|c|c|}
\hline Question Item & Table Indicators & Total Items & SA & $A$ & $D$ & Category \\
\hline $\begin{array}{l}\text { 1. Do you agree with the } \\
\text { weekly market in the complex } \\
\text { where you live? }\end{array}$ & 1 & 1 & $56 \%$ & $32 \%$ & $12 \%$ & Strongly Agree \\
\hline $\begin{array}{l}\text { 3. The market is always } \\
\text { crowded with visitors }\end{array}$ & 2 & 1 & $44 \%$ & $55 \%$ & $1 \%$ & Agree \\
\hline $\begin{array}{l}\text { 4. Strategic Weekly market } \\
\text { position }\end{array}$ & 3 & 1 & $46 \%$ & $42 \%$ & $12 \%$ & Strongly Agree \\
\hline $\begin{array}{l}\text { 6. Do you agree that the } \\
\text { weekly market is only held } \\
\text { once a week? }\end{array}$ & 4 & 1 & $18 \%$ & $24 \%$ & $58 \%$ & Disagree \\
\hline $\begin{array}{l}\text { 7. The existence of a weekly } \\
\text { market really disturbs my }\end{array}$ & 5 & 1 & $8 \%$ & $21 \%$ & $71 \%$ & Disagree \\
\hline $\begin{array}{l}\text { 14. Better to shop in the weekly } \\
\text { market than shopping in the } \\
\text { modern market }\end{array}$ & 6 & 1 & $38 \%$ & $47 \%$ & $15 \%$ & Agree \\
\hline
\end{tabular}


Table 2 Recapitulation of Public Perceptions Regarding the Benefits of the Weekly Market on Jalan Tangkasala, Indicators of Market Benefits

\begin{tabular}{|c|c|c|c|c|c|c|}
\hline Question Item & Table Indicators & Total Items & SA & A & $\mathrm{D}$ & Category \\
\hline $\begin{array}{l}\text { 2.The weekly market is very } \\
\text { helpful to the community }\end{array}$ & 8 & 1 & $53 \%$ & $35 \%$ & $12 \%$ & Strongly Agree \\
\hline $\begin{array}{l}\text { 11. My needs are met because } \\
\text { there is a weekly market }\end{array}$ & 9 & 1 & $18 \%$ & $52 \%$ & $30 \%$ & Agree \\
\hline $\begin{array}{l}\text { 16.Shopping in the weekly } \\
\text { market has more economic } \\
\text { benefits because it is close to } \\
\text { home }\end{array}$ & 10 & 1 & $41 \%$ & $47 \%$ & $12 \%$ & Agree \\
\hline $\begin{array}{l}\text { 17. Young children are } \\
\text { entertained by the games on } \\
\text { the weekly market }\end{array}$ & 11 & 1 & $52 \%$ & $48 \%$ & $0 \%$ & Strongly Agree \\
\hline $\begin{array}{l}\text { 18. Games for children on the } \\
\text { weekly market have the same } \\
\text { affordable rates as children's } \\
\text { entertainment venues in } \\
\text { general }\end{array}$ & 12 & 1 & $50 \%$ & $50 \%$ & 0 & Agree \\
\hline $\begin{array}{l}\text { 19. Communities around the } \\
\text { neighborhood who are close to } \\
\text { the weekly market benefit } \\
\text { economically because they can } \\
\text { participate in opening a } \\
\text { business }\end{array}$ & 13 & 1 & $50 \%$ & $50 \%$ & $0 \%$ & Agree \\
\hline $\begin{array}{l}\text { 20.The weekly market must still } \\
\text { exist to help the local } \\
\text { community's economy and } \\
\text { make it easier for residents to } \\
\text { buy and sell transactions }\end{array}$ & 14 & 1 & $52 \%$ & $36 \%$ & $12 \%$ & Strongly Agree \\
\hline
\end{tabular}

4.3.Perceptions of the Mahir Mahar Housing Complex Community on Social Interaction in Organizing the Weekly Market During the COVID-19 Pandemic on Jalan Tangkalasa Palangka Raya.

The results of the question analysis (Table 3) show that there is social interaction in the market, indicated by $65 \%$ of the people who agree that traders are friendly when they visit.

\subsection{Perceptions of the Mahir Mahar Housing Complex Community about the Cleanliness of the Weekly Market during the COVID-19 Pandemic on Jalan Tangkalasa, Palangka Raya.}

In table 4 , it can be seen that $76 \%$ of the people disagree with the statement of the state of the net weekly market environment. Likewise, $47 \%$ disagreed with the statement regarding the application of the health protocol. This shows that the weekly market environment is not clean or dirty. In addition, it also shows that the health protocols implemented in the weekly market area have not been fully implemented 
Table 3. Recapitulation of Public Perceptions about Social Interactions That Occur during the Weekly Market

\begin{tabular}{|l|c|c|c|c|c|c|}
\hline \multicolumn{1}{|c|}{ Question Item } & Table Indicators & Total Items & SA & A & D & Category \\
\hline $\begin{array}{l}\text { 8. The salesmen were friendly } \\
\text { when I visited the market }\end{array}$ & 16 & 1 & $20 \%$ & $65 \%$ & $15 \%$ & Agree \\
\hline $\begin{array}{l}\text { 21.I have a desire to sell on the } \\
\text { weekly market }\end{array}$ & 17 & 1 & $0 \%$ & $38 \%$ & $62 \%$ & Disagree \\
\hline
\end{tabular}

Table 4. Recapitulation of Public Perceptions of the Weekly Market

\begin{tabular}{|l|c|c|c|c|c|c|}
\hline \multicolumn{1}{|c|}{ Question Item } & Table Indicators & Total Items & SA & A & D & Category \\
\hline $\begin{array}{l}\text { 5. The state of the weekly } \\
\text { market environment is clean }\end{array}$ & 19 & 1 & $5 \%$ & $19 \%$ & $76 \%$ & Disagree \\
\hline $\begin{array}{l}\text { 15. Traders and visitors have } \\
\text { implemented health protocols } \\
\text { to reduce the spread of COVID- } \\
19\end{array}$ & 20 & 1 & $15 \%$ & $38 \%$ & $47 \%$ & Disagree \\
\hline
\end{tabular}

Table 5 Recapitulation of Public Perceptions about the Safety of the Sunday Market

\begin{tabular}{|l|c|c|c|c|c|c|}
\hline \multicolumn{1}{|c|}{ Question Item } & Table Indicators & Total Items & SA & A & D & Category \\
\hline $\begin{array}{l}\text { 12.Security in a conducive } \\
\text { market environment }\end{array}$ & 22 & 1 & $6 \%$ & $70 \%$ & $24 \%$ & Agree \\
\hline $\begin{array}{l}\text { 13. Parking fees should be } \\
\text { removed }\end{array}$ & 23 & 1 & $74 \%$ & $26 \%$ & $0 \%$ & Strongly Agree \\
\hline $\begin{array}{l}\text { 22. I feel disturbed by the } \\
\text { weekly market activity due to } \\
\text { traffic jams }\end{array}$ & 24 & 1 & $6 \%$ & $33 \%$ & $61 \%$ & Disagree \\
\hline $\begin{array}{l}\text { 23. I was disturbed by the } \\
\text { hustle and bustle }\end{array}$ & 25 & 1 & $9 \%$ & $30 \%$ & $61 \%$ & Disagree \\
\hline
\end{tabular}

\subsection{Perceptions of the Mahir Mahar Housing} Complex Community about the Safety of the Weekly Market during the COVID-19 Pandemic on Jalan Tangkalasa, Palangka Raya.

From table 5 it can be concluded that the weekly market is quite safe. This can be seen from $70 \%$ of the public agree that the market environment is conducive to safety. In addition, the community is also not disturbed by the crowds caused by the weekly market. $61 \%$ of the people disagree if they feel disturbed and $61 \%$ also disagree if they are disturbed by the hustle and bustle of the crowd.
4.6.Perceptions of the Mahir Mahar Housing Complex Community about the Quality of Weekly Market Trade during the COVID19 Pandemic on Jalan Tangkalasa Palangka Raya.

Based on table 6 , it can be seen that the quality of weekly market trade is of sufficient quality. As many as $91 \%$ of the people agree with the statement that the vegetables and side dishes sold in the weekly market are still fresh. The community, amounting to $70 \%$, also agrees that the goods sold in the weekly market are affordable. 
Table 6 Recapitulation of Public Perceptions Regarding the Quality of Weekly Market Trade

\begin{tabular}{|l|c|c|c|c|c|c|}
\hline \multicolumn{1}{|c|}{ Question Item } & Table Indicators & Total Items & SA & A & D & Category \\
\hline $\begin{array}{l}\text { 9. The vegetables and side } \\
\text { dishes sold in the weekly } \\
\text { market are still fresh }\end{array}$ & 27 & 1 & $6 \%$ & $91 \%$ & $3 \%$ & Agree \\
\hline $\begin{array}{l}\text { 10. Items sold in the weekly } \\
\text { market are reasonably priced }\end{array}$ & 28 & 1 & $6 \%$ & $70 \%$ & $24 \%$ & Agree \\
\hline
\end{tabular}

Based on the research data obtained, especially those related to existing theoretical assistance, distributing questionnaires, problem formulation, data analysis, linking data and estimating data relevant to this subject matter, the results of the discussion are as follows:

\subsection{Market Presence}

Based on table 1, from 6 statements, the frequency distribution of 66 respondents gave the highest responses to the 'agree' option, while $35 \%$ were 'strongly agree', and $28 \%$ were 'disagree'. This percentage shows that the members of RT 003 RW XIV agree with the existence of a weekly market. Thus, it can be concluded that the existence of a weekly market in the Mahir Mahar housing complex km.8 Palangka Raya was approved by the residents of RT 003 RW XIV.

\subsection{Market Benefits}

Based on Table 2, from 7 statements, the frequency distribution of 66 respondents have the highest responses to the 'agree' option (46\%), while $45 \%$ were 'strongly agree', and only $9 \%$ were 'disagree'. It means that the members of RT 003 RW XIV agree with the benefits of the weekly market nearby. Thus, it can be concluded that the public feels the weekly market is useful in the Mahir Mahar Km housing complex 8 Palangka Raya

\subsection{Social Interaction}

Based on Table 3, from 2 statements, the frequency distribution of 66 respondents have the highest responses to the 'agree' option (51.5\%), while 38.5\% were 'disagree', and only $10 \%$ were 'strongly agree'. It means that the members of RT 003 RW XIV agree with the various types of social interaction that occur during the weekly market. Thus, it can be concluded that social interaction during the weekly market does exist and works well in the Mahir Mahar Km.8 housing complex, Palangka Raya

\subsection{Cleanliness}

Based on table 4 , the frequency distribution of the 66 respondents who were given 2 (two) statements can be obtained by the percentage of the answers "strongly agree" as much as $36 \%$, "agree" as much as $21 \%$, and "disagree" as much as $43 \%$. The answer turned out to have the highest percentage of "disagree" answers as much as $43 \%$, according to [11] it is included in the agreeing category.

The discussion of the results of this study means that the public does not agree with the cleanliness of the market environment, or rather the market environment is dirty. Thus it can be concluded that the residents agree that the weekly market is located in the Mahir Mahar $\mathrm{km}$ housing complex. 8 Palangka Raya has a dirty environment.

\subsection{Security}

Based on table 5, the distribution of the 66 respondents who were given 4 (four) points of statement can be obtained the percentage of answers "strongly agree" as much as $23.75 \%$, "agree" as much as $39.75 \%$, and "disagree" as much as $36.5 \%$. The answer turned out to be the highest percentage of answers "agree" as much as $39.75 \%$, this percentage according to [11] is in the agree category.

Discussion of the results of this study means that the public agrees with a conducive market security and is not disturbed by all the activities and hustle and bustle that occurs in the market. Thus it can be concluded that the residents of RT 003 RW XIV feel safe under control when the weekly market takes place.

\subsection{Quality of Market Merchandise}

Based on table 6, the distribution of the 66 respondents who were given 2 (two) points of statement, the percentage of answers was $6 \%$ "strongly agree", "agree" as much as $80.5 \%$, and "disagree" as much as $13.5 \%$. The answer turned out to be the highest percentage of answers "agree" as much as $80.5 \%$, this 
percentage according to [11] is categorized as strongly agree.

The discussion of the results of this study means that the residents strongly agree that the quality of goods or merchandise sold in the market is good or fresh for side dishes or vegetables as well as affordable merchandise prices. Thus it can be concluded that the quality of the market place is highly approved by the residents of RT 003 RW XIV.

\section{CONCLUSIONS}

Based on the results of research data analysis and the results of research discussion, the conclusions are as follows. Firstly, descriptively the community's perception of the existence of the community market RT 003 RW XIV agrees with the existence of a weekly market. Thus it can be descriptively the community's perception of the existence of the community market RT 003 RW XIV agrees with the existence of a weekly market. Secondly, community RT 003 RW XIV agrees with the benefits that people can feel because of the weekly market near where they live. Thus it can be concluded that the public feels the weekly market is useful in the Mahir Mahar $\mathrm{Km}$ housing complex. 8 Palangka Raya

Next, the community agrees with the various types of social interactions that occur when the weekly market takes place. Thus, it can be concluded that social interaction during the weekly market does exist and is running well in the Mahir Mahar Km.8 housing complex, Palangka Raya. In addition, the community does not agree with the cleanliness in the market environment, or rather the market environment is dirty. Thus it can be concluded that the residents agree that the weekly market is located in the Mahir Mahar km housing complex. 8 Palangka Raya has a dirty environment.

Lastly, the community agrees with a conducive market security and is not disturbed by all the activities and hustle and bustle that occurs in the market. Thus it can be concluded that the residents of RT 003 RW XIV feel safe under control when the weekly market takes place. The community strongly agrees that the quality of goods or merchandise sold in the market is good or fresh for side dishes or vegetables as well as affordable prices. Thus it can be concluded that the quality of the market place is highly approved by the residents of RT 003 RW XIV

\section{REFERENCES}

[1] N. Purkayastha, "Weekly Market: A Micro Level Study on Byrnihat Market in Ri- Bhoi District of Meghalaya.," EPRA Int. J. Multidiscip. Res. (IJMR)., vol. 5, 2020.
[2] M. A. Ahteshan, "An Analysis on Weekly Market of Ruabandha (Local Area Plan), Bhilal (C.G)," CSVTU Res. J. Swarni Vivekanand Techical Univ., vol. 9, no. 1, pp. 49-57, 2020.

[3] P. A.Partanto, Kamus Ilmiah Populer. Surabaya: Arkola.

[4] C. Wade and C. Travis, Psychology. Jakarta: Erlangga, 2009.

[5] J. Rakhmat, Psikologi Komunikasi. Bandung: Remaja Rosdakarya, 2008.

[6] N. Nazsir, Sociology. Jakarta: Bulan Bintang, 2009.

[7] Y. 2007 RI Presidential Regulation No. 112, No. .

[8] T. Kristin, The Role of Traditional Markets as a Basic Foundation for a Populist Economy. 2014.

[9] S. I. Thesis, The Existence of Tais Weekly Market in Bengkulu City. 2016.

[10] et al. Atmojo, J.T, "Definition and Transmission Route of Severe Acute Respiratory Syndrome Coronavirus 2 (Sars-Cov-2) or Covid-19," EJournal Heal. Educ., vol. 9 (1), pp. 57-64, 2020.

[11] W. Surachmad, Introduction to Scientific Research. Bandung: Tarsino, 2008 